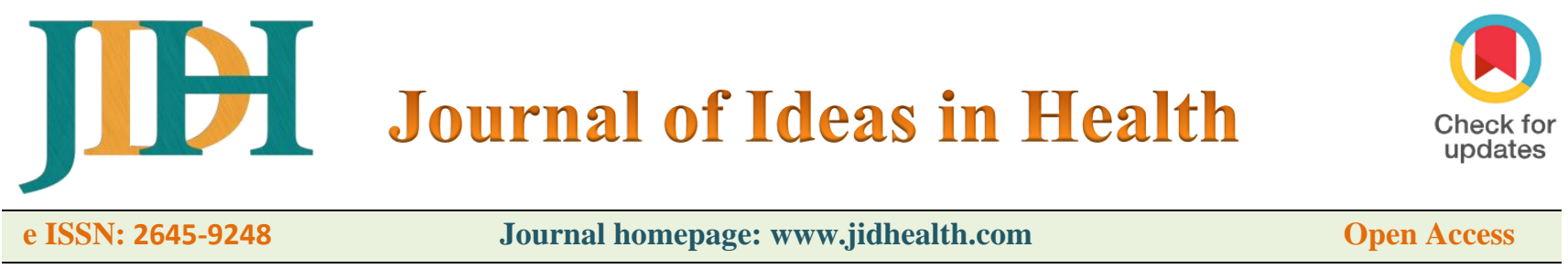

Review Article

\title{
Laboratory manifestations of COVID-19 associated with hemostatic abnormalities
}

\author{
Ahmed Elhadi Elsadig ${ }^{1}$, May Mohammed Ali², Alfatih Aboalbasher Yousif ${ }^{*}$
}

\begin{abstract}
Hemostatic abnormalities had been reported in COVID-19 patients, which may include disseminated intravascular coagulation (DIC), hypercoagulability, and alterations in platelets parameters. Articles that investigate the alterations of hemostatic abnormalities during the COVID-19 disease (2020-2021) and their predictive value of disease outcome have been thoroughly reviewed. Among the reviewed articles, thrombocytopenia is observed in $5.0-41.7 \%$ of COVID19 patients, which is related to disease severity. Moreover, other platelets parameters, including Platelets/lymphocytes ratio (PLR), Mean platelets volume (MPV), and aggregation, may also be affected. On the other hand, findings of coagulation tests such as D dimer; fibrinogen, Antithrombin (AT), and Fibrin degradation products (FDP) are significantly elevated in COVID-19 patients, while in a single study, most of the patients had positive Lupus anticoagulants (LA) and normal protein C (PC). In the same perspective, these alterations showed significant correlations with disease severity. Overall, hemostatic laboratory markers are significant predictors of COVID-19 disease outcome as indicated by the increased risk of venous and arterial thrombotic events, especially in ICU patients.
\end{abstract}

Keywords: COVID-19, Venous thromboembolism, D-Dimer, Thrombocytopenia, Fibrinogen Degradation Products, Oman, Sudan

\section{Background}

Coronavirus disease (COVID-19) was first reported in Wuhan, China, in December 2019, then declared by WHO in March 2020 as a pandemic disease due to its high infectivity and worldwide spreading [1]. Among hospitalized patients, the mortality rate is about $11.5-13 \%$ [2], while $10 \%$ of infected patients develop severe respiratory symptoms. On the other hand, $\sim 80 \%$ of patients may be asymptomatic or with mild symptoms [3]. Hemostatic alterations had been noted in COVID-19 patients, which may include variations in platelets count and/or other parameters, Disseminated intravascular coagulation (DIC), and hypercoagulability. Patients with a low grade of the disease may have normal or increased platelet count [4], while critical patients may have thrombocytopenia. DIC is demonstrated in $70 \%$ of non-survivor patients as indicated by raised plasma fibrin degradation products (FDPs) and D-Dimer [5]. Also, the reduction in platelets count may associates with lung injury leading to pulmonary intravascular coagulopathy [6]. In the same perspective, some COVID-19 patients may develop serious hypercoagulability complications,

*Correspondence: alfbadf@yahoo.com

${ }^{1}$ Pathology Department, Ibra Hospital, Ministry of Health - Oman.

Full list of author information is available at the end of the article which are associated with the severity of the disease; these manifest as thrombotic events in the kidney, lungs, heart, and other organs [7]. On the other hand, several studies reported that COVID-19 is associated with elevated levels of prothrombin time (PT), activated partial thromboplastin time (APTT), and Ddimer [3], which associates with a greater risk of mortality among hospitalized patients [8].

\section{Alterations in Platelets parameters}

Quantitative and qualitative platelets abnormalities have been described in COVID-19 patients, which does not necessarily associate with clinical signs, but commonly they showed correlations with disease severity. These include thrombocytopenia, increased mean platelets volume (MPV), and platelets aggregation.

\section{Thrombocytopenia}

Thrombocytopenia is observed in 5.0-41.7 \% of COVID-19 patients with variable degrees, which is reflected by disease severity [9,10]. Mild thrombocytopenia (Platelet's count < 150x109/1) is detected in 58-95\% of COVID-19 cases [11], while severe thrombocytopenia $(>50 \times 109 / 1)$ is rarely observed [12]. Thrombocytopenia develops due to the consumption of platelets during the course of the infection, as they are observed in alveolar sections together with megakaryocytes which is a 
unique finding of COVID-19 [13]. Moreover, this finding is supported by Liu et al., who studied the dynamic alterations in thrombocytes among hospitalized patients and claimed that inspection of platelets count has an important role in the prognosis of the disease [14]. Another quantitative platelet parameter evaluated in COVID-19 patients is the platelets/lymphocytes ratio (PLR). Yang AP et al. [15] found that PLR is increased in COVID-19 patients and could be used as a prognostic marker for this disease with specificity and sensitivity of 0.44 and 0.77 , respectively, and a cutoff value of 180 [15]. COVID-19 showed an association with Idiopathic thrombocytopenic purpura (ITP) in elders as described in a systematic review by Bhattacharjee and Banerjee, who reported that COVID19-associated ITP cases, 71\% were older than 50 years and had moderate to severe disease [16]. Pseudo thrombocytopenia is also reported in some COVID-19 cases due to Ethylene diamine tetra acetic acid (EDTA)-dependent antibodies. In one report, platelets count was normal at admission time, then progressively decreased with aggregated platelets in the peripheral blood smear but with no signs of bleeding. When performed in a citrated blood sample, platelets count return to normal, and the phenomenon disappeared 17 days later [17].

\section{Mean Platelet Volume}

In addition to thrombocytopenia, COVID-19 seems to affect the MPV as reported by Liu et al. study, which revealed that thrombocytopenic patients had significantly higher mean platelet volume (MPV, median $10.3 \mathrm{fL}$ ) than COVID- 19 patients with retained platelet counts (median $9.9 \mathrm{fL}$ ) [5]. Patients with COVID-19 are associated with increased production of large immature platelets as a response of megakaryocytes to the increased platelet consumption; thereafter, COVID-19 is characterized by greater numbers of immature platelets even with normal platelets counts. As immature platelets are more functionally active, this could be an additional contributing factor for the hypercoagulability associated with COVID-19 [18]. Platelet's parameters and COVID-19 disease severity are shown in table 1.

Table 1. Association of platelets parameters and COVID-19 disease severity

\begin{tabular}{|c|c|c|c|c|c|c|}
\hline Marker & Results & $\begin{array}{l}\text { Number of } \\
\text { Patients }\end{array}$ & Severity & $\begin{array}{l}\text { Average } \\
\text { age }\end{array}$ & $\begin{array}{l}\text { Statistic } \\
\text { Test }\end{array}$ & Authors [Ref] \\
\hline $\begin{array}{l}\text { Platelets/Lymphocytes } \\
\text { ratio (PLR) }\end{array}$ & Increased & 93 Patients & $\begin{array}{l}\text { Significant } \\
\text { association }\end{array}$ & 58 Years & $P<0.001$ & Yang AP, et al. [15] \\
\hline Thrombocytopenia & $\begin{array}{l}\text { In mild cases } \\
\left.<150 \times 10^{9} / 1\right) \\
\text { In severe cases } \\
\left(>50 \times 10^{9} / 1\right)\end{array}$ & 383 Patients & $\begin{array}{l}\text { Significant } \\
\text { association }\end{array}$ & 46 years & $P<0.05$ & Liu Y, et al. [14] \\
\hline $\begin{array}{l}\text { Mean Platelets } \\
\text { Volume }\end{array}$ & Normal & 41 Patients & $\begin{array}{l}\text { No significant } \\
\text { association }\end{array}$ & 55 years & NA & Manne BK, et al. [18] \\
\hline Platelets Aggregation & $\begin{array}{l}\text { Increased } \\
\text { platelet } \\
\text { aggregation }\end{array}$ & 41 Patients & $\begin{array}{l}\text { Significant } \\
\text { association }\end{array}$ & 55 years & $P<0.05$ & Manne BK, et al. [18] \\
\hline
\end{tabular}

\section{Platelet's aggregation}

As mentioned above, reduction in circulating platelets count is related to their consumption via intravascular aggregation during the formation of pulmonary thrombi. In the same perspective and in a recent study, circulating platelets from COVID-19 patients showed increased membrane expression of P-selectin, a crucial adhesion molecule. Furthermore, platelets from COVID-19 patients showed a faster aggregation response and increased interaction with collagen and fibrinogen [18].

\section{Coagulation disturbances}

Significant alterations of coagulation testing had been observed in COVID-19 patients. These include elevations of plasma DDimer, Fibrinogen, and FDPs, reduction in plasma level of AT, and presence of lupus anticoagulants. These alterations may associate with thrombotic events.

\section{D-Dimer and FDPs levels}

Elevated plasma D-dimer levels (> 500ng/ml) are among the markers of hypercoagulability associated with COVID-19. Furthermore, the elevation of plasma D-Dimer level showed a significant correlation with the disease severity [4]. Thus, D-
Dimer may serve as a good prognostic marker for identifying patients who need critical care [19]. In a retrospective study, a multivariate regression test was applied to variables on hospitalized COVID-19 patients. Among the tested predictors, elevated D-Dimer in addition to other coagulation and inflammatory markers at initial presentation were significant predictors of coagulation complications (thrombosis or bleeding), critical illness, and death [20]. In the same perspective, a case-control study showed that elevated D-Dimer is a significant predictor of in-hospital mortality with a sensitivity of $88.2 \%$ and specificity of $71.3 \%$ [21]. Plasma fibrinogen and its FDPs were also evaluated in COVID-19 patients. Han et al. reported that plasma levels of fibrinogen and FDPs in addition to D-dimer were all elevated significantly among COVID-19 patients compared to healthy controls. Furthermore, D-dimer and FDP were progressively increased with increased disease severity, but the fibrinogen level remains static [22].

Anti-thrombin and Lupus anticoagulants

Anti-thrombin (AT) and protein c (PC) systems are the main plasma physiological anticoagulants produced by the liver. 
Reduction in these coagulation regulators is commonly associated with the risk of thrombosis. Evaluation of AT level among COVID-19 patients revealed that $55 \%$ of cases had AT levels below the reference range, while protein $\mathrm{C}$ was not affected [23]. Another thrombotic risk factor was observed in COVID-19, which is the lupus anticoagulants. Bowles et al. observed lupus anticoagulants in 91\% of COVID-19 patients who had prolonged screening APTT [24]. Coagulation tests and their association with COVID-19 disease severity in some studies are shown in table 2 .

\section{Thrombotic disease in COVID-19}

Thrombotic events in hospitalized COVID-19 patients may include pulmonary embolism, venous thromboembolic events such as proximal deep vein and upper extremity thrombosis, and arterial thromboembolic events such as ischemic strokes. These thrombotic complications showed an association with the severity of the disease; thereafter, they are commonly observed in severely ill patients in approximately $25-31 \%$ of ICUadmitted COVID-19 patients [2].

\section{Discussion}

From all the above, hypercoagulability is the most prominent hemostatic abnormality encountered in COVID-19 patients [4]. It is related to the pro-coagulant effect of the accompanied inflammatory status of the disease, which associates with increased thrombin generation and involvement of blood platelets in the reaction. Widespread inflammatory reaction may lead to the systemic prothrombotic status, which is an initiating event of acute DIC, while the chronic phase of DIC is characterized by hypercoagulability resulting from consumption of hemostatic elements, including the platelets $[5,6]$.

Among the laboratory markers of hemostatic disturbance, DDimer is consistently elevated in COVID-19 patients experiencing hemostatic defects. Moreover, it showed significant predictive power for disease severity and mortality risk $[4,5]$. Thereafter, this test could be used as a sensitive and specific predictor of hemostatic complications in COVID-19 patients [19]. Among the other markers, thrombocytopenia is another indicator of hemostatic disturbance resulting from circulating platelets' consumption during the associated prothrombotic status [14]. The degree of thrombocytopenia reflects the severity of the hemostatic defect, which in turn is related to the severity of the COVID-19 $[14,18]$.

So, in conclusion, COVID-19 patients should have a baseline hemostatic profile, including plasma D-Dimer assay and platelets count. Then patients with elevated D-Dimer and/or thrombocytopenia should be considered at risk of serious hemostatic complications and should be managed accordingly.

\section{Conclusion}

Hemostatic disturbances, mainly thrombotic events, were reported among COVID-19 patients in association with disease severity. Furthermore, hemostatic laboratory markers are significant predictors of disease outcome, including critical illness and mortality.

Table 2. Association of elevated D-Dimer and abnormal coagulation tests results with COVID-19 disease severity and mortality

\begin{tabular}{|c|c|c|c|c|c|}
\hline Author [Ref] & $\begin{array}{l}\text { The article, } \\
\text { Study design }\end{array}$ & $\begin{array}{l}\text { Patients } \\
\text { (n) }\end{array}$ & $\begin{array}{l}\text { D-Dimer } \\
\text { Mean }\end{array}$ & $\begin{array}{l}\text { Markers of severity and } \\
\text { mortality }\end{array}$ & Other findings \\
\hline $\begin{array}{l}\text { Panigada } \quad M \text {, et } \\
\text { al.[4] }\end{array}$ & $\begin{array}{l}\text { Brief report } \\
\text { (Retrospective } \\
\text { study) }\end{array}$ & 24 & $4877 \mathrm{ng} / \mathrm{ml}$ & $\begin{array}{l}\text { - All were ICU, intubated } \\
\text { patients } \\
\text { - Signs of PE, DVT, and } \\
\text { severe inflammation }\end{array}$ & $\begin{array}{l}\text { - Normal PT\&APTT } \\
\text { - Increased Fbg, VWF, FVIII, } \\
\text { and PC }\end{array}$ \\
\hline Tang N, et al. [5] & $\begin{array}{l}\text { Brief report } \\
\text { (Retrospective } \\
\text { study) }\end{array}$ & 183 & $\begin{array}{l}\text { 610ng/ml in } \\
\text { survivors and } 2120 \text { in } \\
\text { non-survivors } \quad(p . \\
\text { value }<.001)\end{array}$ & $\begin{array}{l}\text { - The mortality rate is } 11.5 \% \\
\text { - DIC in } 71.4 \% \text { of non- } \\
\text { survivors }\end{array}$ & $\begin{array}{l}\text {-Significantly elevated PT and } \\
\text { FDPs in non-survivors }\end{array}$ \\
\hline $\begin{array}{l}\text { Zhang L, et al. } \\
\text { [19] }\end{array}$ & $\begin{array}{l}\text { Brief report } \\
\text { (Retrospective } \\
\text { study) }\end{array}$ & 343 & $\begin{array}{l}>200 \mathrm{ng} / \mathrm{ml} \text { in } 67 \\
\text { patient }(20 \%)\end{array}$ & - 13 in-hospital death. & $\begin{array}{l}\text { Elevated D-Dimer }>200 \mathrm{ng} / 1 \\
\text { associated with a higher risk of } \\
\text { mortality } \quad(\mathrm{P}<.001 ; \quad \text { hazard } \\
\text { ratio51.5, CI } 12.9-20.7)\end{array}$ \\
\hline $\begin{array}{l}\text { Al-Samkari } \mathrm{H} \text {, et } \\
\text { al. [20] }\end{array}$ & Original article & 400 & $\begin{array}{lr}>1000 \mathrm{ng} / \mathrm{ml} & \text { in } \\
\text { patients } & \text { with } \\
\text { thrombotic } & \text { events } \\
(\mathrm{n}=38) & \end{array}$ & $\begin{array}{lll}-144(36 \%) & \text { critically } & \text { ill, } \\
\text { deaths } & \text { within } & \text { the } \\
27(18.75 \%) & & \end{array}$ & $\begin{array}{l}\text { Thrombosis predicted with high } \\
\text { D-Dimer [Odd 6.79, 95\% CI } \\
\text { 2.39-19.30] }\end{array}$ \\
\hline Yao Y, et al. [21] & $\begin{array}{l}\text { Original article } \\
\text { (Case-control } \\
\text { study) }\end{array}$ & 248 & $\begin{array}{l}>200 \mathrm{ng} / \mathrm{ml} \text { in } 74.6 \% \\
\text { of cases }\end{array}$ & $\begin{array}{l}\text {-In-hospital mortality rate } \\
6.9 \%\end{array}$ & $\begin{array}{l}\text { In-hospital mortality predicted } \\
\text { with high D-Dimer with a } \\
\text { sensitivity of } 88 \% \text { and } \\
\text { specificity of } 71.3 \%\end{array}$ \\
\hline Han H, et al. [22] & Original article & 94 & $\begin{array}{l}\text { Significantly elevated } \\
\text { in patients compared } \\
\text { with controls } \\
(\mathrm{P}<0.001)\end{array}$ & $\begin{array}{l}-35(37 \%) \text { patients with } \\
\text { severe disease } \\
-10(10.6 \%) \text { patients were } \\
\text { critically ill }\end{array}$ & $\begin{array}{l}\text { - Significantly higher Fbg and } \\
\text { lower AT }(\mathrm{P}<0.001) \text { in severely } \\
\text { ill patients compared with mild } \\
\text { disease }\end{array}$ \\
\hline $\begin{array}{l}\text { Bowles L, et al. } \\
{[24]}\end{array}$ & $\begin{array}{l}\text { Letter to the } \\
\text { editor } \\
\text { (retrospective } \\
\text { cohort) }\end{array}$ & 35 & N.A & $\begin{array}{l}\text {-Venous thrombosis in } 3 \% \\
\text { of cases }\end{array}$ & $\begin{array}{l}\text {-Prolonged APTT } \\
\text {-High factor VIII } \\
\text { - Positive LA in } 91 \% \text { of cases }\end{array}$ \\
\hline
\end{tabular}




\section{Abbreviation}

APTT: Activated Partial Thromboplastin Time; AT: AntiThrombin; COVID: Corona Virus Disease; DIC: Disseminated Intravascular Coagulation; EDTA: Ethylene Diamine Tetra Acetic acid; Fbg: Fibrinogen; FDPs: Fibrin Degradation Products; ITP: Idiopathic Thrombocytopenic Purpura; LA: Lupus anticoagulants; MPV: Mean Platelets Volume; N.A: Not applicable, PLR: Platelets Large cell Ratio; PT: Prothrombin Time; PC: Protein C; VTE: Venous Thromboembolism

\section{Declaration}

Acknowledgment

None.

\section{Funding}

The authors received no financial support for their research, authorship, and/or publication of this article.

Availability of data and materials

Data will be available by emailing alfbadf@yahoo.com

\section{Authors' contributions}

May Mohammed Ali (MMA) and Ahmed Elhadi Elsadig (AEE) have contributed equally to the original draft's study concept, design, writing of the original draft. Alfatih Aboalbasher Yousif (AAY) has reviewed and edited the manuscript. All authors read and approved the final manuscript.

Ethics approval and consent to participate

We conducted the research following the Declaration of Helsinki. However, the :Review Article" needs no ethics committee approval.

\section{Consent for publication}

Not applicable

\section{Competing interest}

The authors declare that they have no competing interest.

\section{Open Access}

This article is distributed under the terms of the Creative Commons Attribution 4.0 International License (http://creativecommons.org/licenses/by/4.0/), which permits unrestricted use, distribution, and reproduction in any medium, provided you give appropriate credit to the original author(s) and the source, provide a link to the Creative Commons license, and indicate if changes were made. The Creative Commons Public Domain Dedication

waiver (http://creativecommons.org/publicdomain/zero/1.0/) applies to the data made available in this article, unless otherwise stated.

Author details

${ }^{1}$ Department of Haematology, Faculty of Medical Laboratory Sciences, Sudan International University, Khartoum-Sudan.

${ }^{2}$ Department of Haematology and Immunohematology, College of Medical Laboratory Sciences, Sudan University of Science and Technology, Khartoum-Sudan.

${ }^{3}$ Pathology Department, Ibra Hospital, Ministry of Health Oman.
Article Info

Received: 12 June 2021

Accepted: 05 August 2021

Published: 18 August 2021

\section{References}

1. Zhou M, Zhang X, Qu J. Coronavirus disease 2019 (COVID-19): a clinical update. Frontiers of medicine. 2020 Apr; 14(2):126-135. https://doi.org/10.1007/s11684020-0767-8

2. Klok FA, Kruip MJ, Van der Meer NJ, Arbous MS, Gommers DA, Kant KM, et al. Incidence of thrombotic complications in critically ill ICU patients with COVID19. Thrombosis research. 2020 Jul 1; 191:145147.https://doi.org/10.1016.thromres.2020.04.013

3. Marietta M, Ageno W, Artoni A, De Candia E, Gresele P, Marchetti M, et al. COVID-19 and haemostasis: a position paper from Italian Society on Thrombosis and Haemostasis (SISET). Blood Transfusion. 2020 May; 18(3):167-169. https://doi.org/10.2450/2020.0083-20

4. Panigada M, Bottino N, Tagliabue P, Grasselli G, Novembrino C, Chantarangkul V, et al. Hypercoagulability of COVID-19 patients in intensive care unit: a report of thromboelastography findings and other parameters of hemostasis. Journal of Thrombosis and Haemostasis. 2020 Jul; 18(7):1738-1742. https://doi.org/10.1111/jth.14850

5. Tang N, Li D, Wang X, Sun Z. Abnormal coagulation parameters are associated with poor prognosis in patients with novel coronavirus pneumonia. Journal of thrombosis and haemostasis. 2020 May; 18(5):1233-1234. https://doi.org/10.1111/jth.14768

6. Xu P, Zhou Q, Xu J. Mechanism of thrombocytopenia in COVID-19 patients. Annals of hematology. 2020 Jun; 99(6):1205-1208. https://doi.org/10.1007/s00277-02004019-0

7. Wrap D, Wang N, Corbett KS, Goldsmith JA, Hsieh CL, Abiona O, et al. Cryo-EM structure of the 2019-nCoV spike in the prefusion conformation. Science. $2020 \mathrm{Mar}$ 13;367(6483):1260-1263. DOI: 10.1126/science. abb2507

8. Letko M, Marzi A, Munster V. Functional assessment of cell entry and receptor usage for SARS-CoV-2 and other lineage B beta coronaviruses. Nature microbiology. 2020 Apr;5(4):562-569. https://doi.org/10.1038/s41564-0200688-y

9. Zhang Y, Zeng X, Jiao Y, Li Z, Liu Q, Ye J, et al Mechanisms involved in the development of thrombocytopenia in patients with COVID-19. Thrombosis research. $\quad 2020 \quad$ Sep 1; 193:110-115. https://doi.org/10.1016/j.thromres.2020.06.008

10. Guan WJ, Ni ZY, Hu Y, Liang WH, Ou CQ, He XJ, et al. Clinical characteristics of coronavirus disease 2019 in China. New England journal of medicine. 2020 Apr 30; 382(18):1708-1720. https://doi.org/10.1056/NEJMoa2002032

11. Thachil J. What do monitoring platelet counts in COVID19 teach us? Journal of Thrombosis and Haemostasis. 2020 Aug; 18(8):2071-2072. https://doi.org/10.1111/jth.14879

12. Bomhof G, Mutsaers PG, Leebeek FW, Te Boekhorst PA, Hofland J, Croles FN, et al. COVID-19-associated immune 
thrombocytopenia. British journal of haematology. 2020 Jul; 190(2): e61-4. https://doi.org/10.1111/bjh.16850

13. Becker RC. COVID-19 update: Covid-19-associated coagulopathy. Journal of thrombosis and thrombolysis. 2020 Jul; 50:54-67. https://doi.org/10.1007/s11239-02002134-3

14. Liu Y, Sun W, Guo Y, Chen L, Zhang L, Zhao S, et al. Association between platelet parameters and mortality in coronavirus disease 2019: retrospective cohort study. Platelets. $2020 \quad$ May 18; 31(4):490-496. https://doi.org/10.1080/09537104.2020.1754383

15. Yang AP, Liu JP, Tao WQ, Li HM. The diagnostic and predictive role of NLR, d-NLR and PLR in COVID-19 patients. International immunopharmacology. $2020 \mathrm{Jul} 1$; 84:106504. https://doi.org/10.1016/j.intimp.2020.106504

16. Bhattacharjee $S$, Banerjee $M$. Immune thrombocytopenia secondary to COVID-19: a systematic review. SN comprehensive clinical medicine. 2020 Sep 19; 2:20482058. https://doi.org/10.1007/s42399-020-00521-8

17. Li H, Wang B, Ning L, Luo Y, Xiang S. Transient appearance of EDTA dependent pseudo thrombocytopenia in a patient with 2019 novel coronavirus pneumonia. Platelets. $2020 \quad$ Aug 17 ; 31(6):825-826. https://doi.org/10.1080/09537104.2020.1760231

18. Manne BK, Delorme F, Middleton EA, Portier I, Rowley JW, Stubben C, et al. Platelet gene expression and function in patients with COVID-19. Blood, The Journal of the American Society of Hematology. 2020 Sep 10; 136(11):1317-1329. https://doi.org/10.1182/blood.2020007214

19. Zhang L, Yan X, Fan Q, Liu H, Liu X, Liu Z, et al. DDimer levels on admission to predict in-hospital mortality in patients with COVID-19. Journal of thrombosis and haemostasis. $2020 \quad$ June; $18(6): 1324-1329$. https://doi.org/10.1111/jth.14859

20. Al-Samkari H, Karp Leaf RS, Dzik WH, Carlson JC, Fogerty AE, Waheed A, et al. COVID-19 and coagulation: bleeding and thrombotic manifestations of SARS-CoV-2 infection. Blood, The Journal of the American Society of Hematology. 2020 Jul 23; 136(4):489-500. https://doi.org/10.1182/blood.2020006520

21. Yao Y, Cao J, Wang Q, Shi Q, Liu K, Luo Z, et al. Ddimer as biomarker for disease severity and mortality in COVID-19 patients: a case-control study. Journal of Intensive care. 2020, 8:49. https://doi.org/10.1186/s40560020-00466-Z

22. Han H, Yang L, Liu R, Liu F, Wu KL, Li J, et al. Prominent changes in blood coagulation of patients with SARS-CoV-2 infection. Clinical Chemistry and Laboratory Medicine (CCLM). 2020 March 16; 58(7): 1116-20. https://doi.org/10.1515/cclm-2020-0188

23. Tan CW, Low JG, Wong WH, Chua YY, Goh SL, Ng HJ. Critically ill COVID-19 infected patients exhibit increased clot waveform analysis parameters consistent with hypercoagulability. American journal of hematology. 2020 Jul; 95(7): E156-158. https://doi.org/10.1002/ajh.25822

24. Bowles L, Platton S, Yartey N, Dave M, Lee K, Hart DP, et al. Lupus anticoagulant and abnormal coagulation tests in patients with Covid-19. New England Journal of Medicine. 2020 Jul 16; 383(3):288-290. https://doi.org/10.1056/NEJMc2013656 